\title{
THE INFLUENCE OF ART AND ARTISTIC AND CREATIVE ACTIVITIES ON THE QUALITY OF INFORMATION ASSIMILATION (COMPLEMENTARY SEMANTIC APPROACH IN EDUCATION)
}

\section{A INFLUÊNCIA DA ARTE E DAS ATIVIDADES ARTÍSTICAS E CRIATIVAS NA QUALIDADE DA ASSIMILAÇÃO DA INFORMAÇÃO (ABORDAGEM SEMÂNTICA COMPLEMENTAR NA EDUCAÇÃO)}

\section{LA INFLUENCIA DEL ARTE Y LAS ACTIVIDADES ARTÍSTICAS Y CREATIVAS EN LA CALIDAD DE LA ASIMILACIÓN DE LA INFORMACIÓN (ENFOQUE SEMÁNTICO COMPLEMENTARIO EN EDUCACIÓN)}

\author{
Irina E. Kashekova ${ }^{1}$ (D) Elena S. Medkova ${ }^{(D)}$, Elena N. Piryazeva ${ }^{3}$ (D)
}

\footnotetext{
${ }^{1}$ Institute of Art Education and Cultural Studies of the Russian Academy of Education, Moscow, Russia.

${ }^{2}$ Institute of Art Education and Cultural Studies of the Russian Academy of Education, Moscow, Russia.

${ }^{3}$ Institute of Art Education and Cultural Studies of the Russian Academy of Education, Moscow, Russia.

Corresponding author:

Irina E. Kashekova

Email: kashekova@yandex.ru
}

How to cite: Kashekova, I. E., Medkova, E. S., \& Piryazeva, E. N. (2021). The influence of art and artistic and creative activities on the quality of information assimilation (complementary semantic approach in education). Revista Tempos e Espaços em Educação, 14(33), e15130. https://doi.org/10.20952/revtee.v14i33.15130

\begin{abstract}
Based on the analysis of studies from various areas of scientific knowledge, the article identifies the resources of art and artistic and creative activities having a positive impact on the development of human intellect, creativity, and mental health. The factors and conditions of the beneficial effect of art and artistic and creative activities on the quality of assimilated information are examined. The opportunity for incorporating the languages and methods of art into education is presented by the complementary semantic approach complementary-semantic approach, which, due to the complementarity of the languages of science and art, is aimed at generating different types of thinking (concrete, symbolic, sign, visual, associative, creative) the synthesis of which allows developing the independence of thinking and the skills of social adaptation and collective problemsolving.
\end{abstract}

Keywords: Complementary semantic spproach. Image. Associative thinking. Spatial model. Artistic and creative activity. 


\section{RESUMO}

Com base na análise de estudos de várias áreas do conhecimento científico, o artigo identifica os recursos da arte e das atividades artísticas e criativas com impacto positivo no desenvolvimento do intelecto humano, na criatividade e na saúde mental. Os fatores e as condições do efeito benéfico da arte e das atividades artísticas e criativas sobre a qualidade da informação assimilada são examinados. A oportunidade de incorporar as linguagens e métodos da arte na educação é apresentada pela abordagem semântica complementar abordagem semântica complementar, que, devido à complementaridade das linguagens da ciência e da arte, visa gerar diferentes tipos de pensamento (concreto, simbólico, signo, visual, associativo, criativo) cuja síntese permite desenvolver a independência de pensamento e as habilidades de adaptação social e resolução coletiva de problemas.

Palavras-chave: Abordagem Semântica Complementar. Imagem. Pensamento associativo. Modelo Espacial. Atividade Artística E Criativa.

\section{RESUMEN}

A partir del análisis de estudios de diversas áreas del conocimiento científico, el artículo identifica los recursos del arte y las actividades artísticas y creativas que tienen un impacto positivo en el desarrollo del intelecto humano, la creatividad y la salud mental. Se examinan los factores y condiciones del efecto beneficioso del arte y las actividades artísticas y creativas sobre la calidad de la información asimilada. La oportunidad de incorporar los lenguajes y métodos del arte en la educación se presenta mediante el enfoque semántico complementario enfoque complementariosemántico, que, por la complementariedad de los lenguajes de la ciencia y el arte, tiene como objetivo generar diferentes tipos de pensamiento (concreto, simbólico). , signo, visual, asociativo, creativo) cuya síntesis permite desarrollar la independencia de pensamiento y las habilidades de adaptación social y resolución colectiva de problemas.

Palabras clave: Enfoque semántico complementario. Imagen. Pensamiento asociativo. Modelo espacial. Actividad artística y creativa.

\section{INTRODUCTION}

Scientific and technological progress has had a noticeable impact on the development of all spheres of human life having launched the process of constant renewal of various elements of reproduction. Society of the 21st century finds itself in a state of information overload: on the one hand, all the experience accumulated by mankind became easily available; on the other hand, the flow of new, sometimes very controversial information is growing. Information presented to an individual by the modern world is impossible to remember. Could it mean that the moment to change the goals and forms of education have come? It appears to be so since the issue of changing the educational paradigm would not have been as acute today. Moreover, while the goals of education in the 21st century are identifiable, the ways of achieving them remain largely ineffective.

What can save the younger generation from information overload is shifting the focus of perception in the developed cultural and historical context. The introduction of visual culture as the predominant way of comprehending reality can serve as a methodological foundation for the compact transfer of the existing body of knowledge based on the proven laws of art and culture in the complementary semantic approach to education.

Modern pedagogics has developed numerous methods through which students obtain and master information, however, these methods do not always present the ways of applying it. Thus, there arises a contradiction: it is not enough to obtain knowledge in the modern world, a person has to also be able to use it in the context of the situation at hand. In this regard, only the development of non-standard thinking and creativity makes it possible to respond to the constantly 
changing living conditions. It is art and artistic and creative activity integrated into the educational process that can most effectively contribute to the high-quality assimilation of information.

\section{PROBLEM STATEMENT}

In the modern dynamic and constantly changing world, the problem of education and educatedness is defined differently compared to the recent past - around two decades ago and to several centuries prior. A truly educated person used to be viewed as an individual possessing encyclopedic knowledge in different areas of science, technology, and art. Such a person was typically achieving personal and professional success. In the present, success depends not so much on the quantity of knowledge as on its quality and the ability to use it and the concept of "educated" is being increasingly often replaced by "creative". Creativity is becoming the leading criterion for success in modern times. "Creativity" is close to "creation" in its interpretation but is not entirely identical to it. The ability to think creatively, as well as the ability to be creative, can be developed through art and artistic activity. Not to mention the fact that it is precisely this way of developing creativity that provides additional "bonuses" in the form of a well-developed emotional sphere, aesthetic taste, value ideas, and personality traits. In this context, the problem arises of how and under what conditions art and artistic and creative activities affect the quality of assimilated information.

The research questions determined by the identified problem include:

1. Does art contain special resources increasing the effectiveness of the educational process and what are these resources?

2. What are the ways and techniques of using the resources of art and artistic and creative activity in the general education system?

3. What are the quality criteria for assimilated information?

The goal of the study is to scientifically substantiate the idea of improving the efficiency and ergonomics of the educational process by the means of art.

\section{METHODS}

In the process of long-term practice-oriented pedagogical activity and its theoretical justification, a conviction emerged that art can become a generator of modern education. The analysis of studies in philosophy, culturology, psychology, physiology, sociology, art studies, and pedagogics associated with the influence of visual perception, associative thinking, motivation for cognition, creativity, and various forms of artistic activity on the development of intelligence, improvement of the emotional sphere, stabilization of mental states, a person's successful selfrealization in life and their profession supports the value of the artistically-shaped form of knowledge presentation in modern pedagogics.

The advantage of the artistic and visual form of presenting information is supported by the studies of prominent Russian and foreign scientists. In answering the above questions, we will rely on the opinion of researchers.

1. The resources of art increasing the effectiveness of the educational process.

\section{Visualization, imagination; the complementarity of science and art, an idea and an image}

W.J. Mitchell, the author of the concept of the "cultural or pictorial turn" in modern culture, proposes four ideas regarding this phenomenon: 1 ) the pictorial turn; 2) the differentiation of an "image" and a "picture"; 3) a "metapicture"; 4) a "biopicture" (Mitchell, 2017).

The positions of Mitchell's conception that are important for us are the following: 
- the specifics of the pictorial turn in modern culture actualizing the visual means of transferring and perceiving information consists in the fact that an image and a metaphor have become the main topics in politics, psychology, sociology, art, and even the very structure of knowledge;

- an "image" and a "picture" are not the same: while a "picture" can be hanged on a wall, an "image" can not;

- the notion of a "metapicture" or a picture containing its picture in itself;

- a "biopicture" related to cloning and visualization at the cellular level has found application in biotechnology. For example, perfluorinated organic molecules ${ }^{1}$ which can facilitate X-ray analysis are the agents of mass spectrometric imaging of tissues.

Mitchell's studies allow us to establish that

1) an image and a metaphor - their understanding and interpretation - consistent with the modern culture provide an understanding of many phenomena in politics, psychology, sociology, art, and even in the structure of knowledge;

2) the use of "images" and "pictures" in education will increase the information content of the studied texts, reveal the idea (image), and show the way to its implementation (for example, pictures in a mind map);

3) modern education is aimed at developing meta-knowledge, i.e. the development of mechanisms for working with knowledge (knowledge engineering). Metasubjectivity or metasubject technologies aimed at eliminating the disconnection of different scientific spheres in the educational process are being introduced into education; metaactivity involving that students master not only knowledge but also the ways of interacting with it is used. The concept of "metapicture" is logically built into this series integrating the results of associative thinking, the results of combinatorial activity, the desire for creative cognition in the visual image ("heuristics");

4) adding new components to entire constructs or replacing some components with others can significantly change the properties, qualities, and even the structure of the whole. Thus, adding the elements of other disciplines, languages, and images to the subject content of mathematics, history, disciplines of the natural science cycle can change the quality of information perception.

With the help of an expressive image, a metaphor, or associative links, a teacher can focus the students; attention on certain elements highlighting their significance in the educational information.

The visual and spatial arts can transmit volumetric content in a compact form encrypting ideas in images.

A.F. Losev describes an image as an embodied idea. "...In an "image", there is nothing that can not be found in an "idea". An "image" .... speaks about the expressed "idea" ... and it is enough to just contemplate the "image" itself ...., to thereby grasp the "idea", too (Losev, 2016). Any idea (including scientific) can be expressed using an image at least in general terms. The image is immaterial but it can only be seen if a material embodiment of it is present.

An "image" represented by a word, sound, or picture can be used both in scientific and artistic knowledge of the world. With the help of an image, any idea can be expressed. At the same time, images are unstable, dynamic, changeable, and perceived differently depending on a person. This fact contributes to the interpretation of the image and its transformation by each person in accordance with the level of their development, life experience, outlook, moral and ethical attitudes, aesthetic tastes, etc. Therefore, a wide field for creativity or a prospect of many options for the embodiment of the image is created.

L.S. Vygotsky notes that tendencies towards compactness are inherent in the essence of the figurative vision. Emphasizing the connection between the mechanisms of imagination and "the dynamics of our internal nervous excitations and the corresponding images". he discussed the mechanisms of the convolution of meanings into images of fantasy: "Man marks grief and mourning 
with black, joy with white, calm with blue, and rebellion with red. Fantasy images provide an internal language for our feelings. This feeling selects particular elements of reality and combines them forming a connection that: is conditioned from within ourselves by our mood rather than externally by the logic of these images themselves" (Vygotsky, 1997). Vygotsky noted that images as products of imagination have a very long history which can be schematically represented as a circular trajectory along which images proceeded in their development. However, all the elements of images are taken from reality by people. Nevertheless, said elements were processed in human thinking over time and eventually turned into products of the imagination. "Having finally incarnated, they returned to reality again but returned with a new active force that changes this reality. This is the full circle of creative activity of the imagination" (Vygotsky, 1997). According to Vygotsky, the "images of fantasy" are the same as "universal artistic values", "primary schemes of images of fantasy", or archetypes.

Thus, it can be stated that images of fantasy create an internal language for human feelings and emotions. These feelings, by association, select individual elements of reality from a child's personal experience and combine forming a new connection.

To enhance the possibilities of transformation, it is important to gain new experiences that will stimulate the addition of new elements to the image.

Complementarity which was first formulated in the first third of the 20th century by N. Bor as a principle in physics presents one of the central principles of quantum mechanics and has acquired the status of a methodological and heuristic principle of science. Bor argued that to comprehend any integral phenomenon reproduced in a sign system, it is effective to use the mutually exclusive use of two languages derived from ordinary logic, this approach expands the logical structure of the language of the subject (Bor, 1961). The outstanding physicist called this phenomenon the principle of complementarity.

Using the principle of complementarity, any phenomenon can be explained through the means of different languages allowing one to have a panoramic view of the presented phenomenon. Since exact languages and methods of science are opposed to allegorical, metaphorical languages and subjective methods of art, their mutually exclusive implementation in the educational process will create conditions of complementarity.

Revealing the possibilities of the synthesis of information presentation forms: verbal, symbolic, and visual, A.A. Kriulina indicates how much we lose in the educational process due to underestimating visual information and provides vivid examples of poetic and artistic creativity where capacious information is presented in an extremely concise manner in a visual form and "the poverty of the language of rational concepts is compensated by artistic images and symbols" (Kriulina, 2003). Illustrating this proposition with an example from the graphics of $\mathrm{H}$. Bidstrup depicting the reaction of people of different temperaments to an accidentally crumpled hat, Kriulina states that these small, compact images can completely replace a long lecture on four types of temperament: "The power contained in the images is combined with the no lesser power of communicating one's own worldview to others" (Kriulina, 2003).

The compactness and accessibility of the visual form of transferring any sort of information were discussed by D.S. Likhachev (2006), lu.M. Lotman (1998), V.P. Zinchenko (1998), and others. They especially stressed the fact that it is the images and symbols that make it possible to experience the world and the phenomena occurring in it and not merely gain knowledge about them.

Zinchenko was the first to use the term "knowledge packing density" in this regard emphasizing that it is much higher for the visual form compared to speech (Zinchenko, 1998).

The use of the visual form of presenting information in education will significantly reduce its volume while increasing the effect of perception.

Another way of packing content into accessible and simple visualization schemes involves using the semantics of cultural codes or archetypes. According to C.G. Jung's definition, an 
archetype is "nothing more than ... the very possibility that has been inherited from ancient times ... through the structures of the brain. There are no innate representations but there is an innate possibility of representations which determines the boundaries of even the most daring fantasy, to a certain extent, ideas a priori the existence of which cannot be judged without the presence of appropriate experience. They appear in the designed material as the regulatory principles of its design" (Jung, 2007).

From the pedagogical standpoint, in the concept of Jung, it is important not only that he found images common to all mankind but also that Jung connected them with the processes of "always returning emotional experiences": "as a mythological motive, the original image is always an effective and re-emerging expression that either awakens a given emotional experience or shapes it accordingly" (Jung, 2001). Jung determined that "the original image is a step preceding the idea, this is the ground for its inception" and, at the same time, "the advantage of the original image over the clarity of the idea is its endowment with life" (Jung, 2005). It is also extremely important that, according to Jung, an archetype is meaningful and presents the initial element from which the myth is formed on the one hand and carries the constructive principles of composition and forms the basis for the compositional organization of a myth on the other hand. Shortly speaking, an archetype can be defined as the unity of thought and form, a sort of "thoughtform". The initial image is a step preceding the idea - it is the foundation on which the idea is "born". The idea is clear and understandable but the image has more life and potential for development which presents its advantage.

The archetypes that exist in the subconscious of every person have their sign and symbolic interpretations reflected in folk art. Mastery over folk art, both theoretical and achieved through artistic and creative activity, teaches us to understand ancient semiotics, and enriches associative thinking and creative imagination.

The definition of archetype given by Jung is very similar to G.W.F. Hegel's definition of the essence of an artistic image which indicates their inner kinship. According to Hegel, art "reveals ... not an abstract essence but its concrete reality"; "The sensible in art is spiritualized since the spiritual is given a sensual form in it" (Hegel, 1968). Hegel concludes that "the relationship between the spirit and a work of art which is the least suitable for the spirit is a purely sensory perception of this work ... in this respect, a person as a sensuously singular opposes sensuously singular things. A person does not address them through universal definitions as a thinking being but is guided in relation to individual objects by individual drives and interests. ... theoretical consideration of things focuses ... on knowing them in their universality, finding their inner essence and law (highlighted by the authors)... reasonable intellect does not belong to a separate subject as such but to a subject which, being single, also contains a universal principle" (Hegel, 1968).

Therefore, the perception of a work of art is a synthetic process that combines thoughts and feelings, intelligence and associations, and knowledge and imagination into a single whole. It appears that the first contact with a work of art occurs at the personal-subjective, "singular" level with the help of feelings and emotions that the work evokes with its content, composition, color, etc. just for me - for a specific viewer. Next, there takes place an analysis which makes the viewer aware of the means by which the artist affects their feelings and involves identifying the features of the style, searching for signs and symbols used by the artist, recalling (or studying) the facts of the author's life that could have influenced the creation of the work. This presents the stage of "universal" definitions available to every thinking person at which the cognition of a work occurs in its universality. The integrity of cognition resides in finding the "inner essence and law" where the "inner essence" is "individual" and the law is "universal". The second stage of perceiving a work of art requires certain knowledge (of styles, historical facts, biographies, symbolic codes, etc.), the ability to compare, contrast, and draw logical conclusions. Thus, the perception and interpretation 
of works of art is a good training not only for the improvement of feelings but also for the development of intelligence, imagination, and the ability to interpret.

Hegel's position on the priority of "universality" over "individual" is supported by modern studies in art perception psychology. According to R. Arnheim, perception is holistic and based on the creation of integral structures, "gestalts": "perception does not begin with particulars, on the contrary, its starting point is universality ... an image is never an exact copy of an object but its structural equivalent," and "artistic perception of an object or an event ... comprises creating a visual model that can be presented as the end result of a whole series of incarnations" (Arnheim, 2007). Arnheim finds confirmation of his idea in the art itself: "the tendency of people to depict round and concentric forms can be found in Western and Eastern art, in the art of Ancient Egypt, as well as in children's drawings ... similar models, as they are subconsciously or consciously formed, are able to symbolize the deepest intuitive understanding of the nature of the cosmos" (Arnheim, 2007).

From the point of pedagogics, artistic perception must contribute to the development of the ability to create visual models of an object or an event. Models can be abstract, geometric, or figurative; combinations of ancient signs and symbols are unconsciously used in them.

lu.M. Lotman proposes that in the archaic system, the interaction of sign systems with different languages did not cause difficulties in understanding information. This effect was determined by the specifics of ancient humans' thinking, its mythological nature. This exact type of consciousness is more aimed at generating associations and modeling new ideas. "The world of children's consciousness - primarily mythological - does not disappear and should not disappear in the mental structure of an adult but continues to function as a generator of associations and one of the active modeling mechanisms ignoring which makes it impossible to understand the behavior of an adult" (Lotman, 1978).

The pedagogical conditions for the preservation of the elements of mythological consciousness generating associations in an adult provide a systematic, purposeful, continuous communication with art (perception and artistic creation). Moreover, the sooner it starts, the better.

The synthesis of Hegel's philosophical positions and pedagogics is supported by the theory of developmental education by V.V. Davydov. Davydov argues that the priority of theoretical knowledge is based on the concept of "meaningful generalization". Cognition should not stop at a mere comparison aimed at identifying the formally common properties, on a simple classification, on the reflection of the external properties of phenomena in their correlation according to the principle of alignment, on illustrative concretization, on formalization at the level of term words, it has to go deeper based on the priority of "a function of a special relationship within the integral system", the search for "genetically initial relations of the integral system as its universal foundation or essence", concretization in the form of "explaining the special and individual manifestations of the integral system from the point of its universal foundation" (Davydov, 1996).

Davydov emphasizes that in the learning process, "students initially seek and identify the initial common "cell" of the material being studied and then, relying on it, deduce the various particular features of the subject. "This sort of assimilation is aimed at identifying the conditions of origin of the content of the concepts being assimilated" (Davydov, 1996). The initial "cells" are represented by "symbols that express the universal in objects". Davydov notes that symbols "will be more primary than the real, sensual, private thing in terms of temporal succession". In turn, this predetermines the priority of theoretical knowledge in education: "disclosure and expression of the mediated existence of things and their universality in symbols is a transition to the theoretical reproduction of reality" (Davydov, 1996). Two propositions from Davydov's studies are valuable for us: 
1. Learning begins with a child identifying the "initial common" point ("cell") of the material being studied, then, based on it, various particular features of the object or phenomenon being studied are built up.

2. The initial "cells", according to Davydov, are represented by "symbols expressing the universal in objects". It is the symbols "that will be more primary than a real, sensual, private thing in terms of temporal sequence". Signs can also be used along with symbols.

Psychotherapist N. Peseschkian used the language of images in the methods of his psychotherapeutic practice. He discovered the effect produced by myths, parables, fables, and legends on changing the opinion and position of patients (Peseschkian, 2006). We believe that the same effect can be obtained using the images of any type of art. Peseschkian described the functions of the legends he used which we will present in full since we consider them important for our research:

1. The mirroring function allows the listener to more easily identify with the content of the stories, that is, they see themselves in the story as if in a mirror.

2. Sample function. Stories contain specific decisions or indications of the consequences of certain decisions.

3. Mediation function manifests in mitigating possible confrontation between the listener's and the narrator's viewpoints.

4. Experience preservation function. Due to the imagery and emotional resonance of the listener, stories are remembered better; if necessary, they are easily retrieved from memory.

5. Transcultural interaction function. Stories from other cultures enrich the listener's experience with the rules of the game, concepts, and norms of behavior adopted in these cultures.

6. Stories as a means of regression help the listener return to earlier, pleasure-oriented behaviors and attitudes.

7. A story is a counter-concept that the narrator offers to the listener who is free to accept or reject it.

If we change the word "story" to the concept of "text of a work" in the listed functions, we will see that these functions are inherent not only in literary works but also in the works of art in general. In this case, the text of a work is understood as information that it carries to us in a figurative form, i.e. "densely packed". This statement is supported by the fact that:

1. A work of any art is aimed at spiritual complicity, emotional empathy from the viewer, reader, or listener; and, as a result, their identification with the content.

2. The purposes of art include the cognitive and predictive functions not only suggesting the presence of options - models for solving various problems but also revealing the possible consequences of the actions taken.

3. Art softens emotional impulses, deprives them of aggressiveness, transforms the state of passion into "smart emotions" (Vygotsky, 1997), and helps to eliminate confrontation between different opinions.

4. Art presupposes emotional involvement in the essence of any text, provides a resonance that makes the text easier to memorize, preserves the sensations that have arisen in the emotional experience of the viewer, listener, or reader.

5. Art enriches the experience of the viewer, reader, or listener with the experience of many generations of people of different cultures.

6. Art helps to restore associative connections and experience previously unknown feelings.

7. Art does not pressure the viewer, reader, or listener but indirectly gives them the freedom to choose their own position on the basis of the author's view presented to them and the disclosure of the possible results of this choice. Thus, it provides freedom of conscious choice.

Many scientists believe that creative search is a preventative measure preserving both the emotional and overall health of people (Bekhterev, 1911; Kuznetsova, 1993; Martin, 1996). A. 
Kozhibsky argues that the human psyche has to be active, a person should constantly work on the discovery of something new, i.e. engage in creativity since it has a positive effect on mental health on which the overall health of the body depends (Iafalian, 2011; Korsybski, 1933).

\section{Development of thoughts, feelings, and emotions}

E. Fromm recognized the essential role of art and its visual images in human life: "Schooling, be it either knowledge transfer or character formation, is only one part of education and perhaps not the most important one if we understand the word "education" in its literal sense: the Latin "et ducere" means to "pull out" what is inherent in a person. If a person possesses knowledge, even if they do their job well, are conscientious, honest, and have a good financial status, they cannot be satisfied. To feel at home in the world, a person must comprehend it not only with their mind but also with all the senses: eyes, ears, with all his body (highlighted by the authors). They have to implement what they invent with their mind using their body. Body and mind cannot be separated.... If a person comprehends the world and thus connects with it through thinking, they create philosophy, theology, myths, and science. If a person expresses their comprehension of the world with the help of their feelings, they create art and rituals, songs, dances, drama, paintings, and sculptures" (Fromm, 2005).

Fromm especially emphasizes the term "collective art", i.e. art that is jointly created. In this definition, he highlighted the word "jointly" believing that it draws a line between the concepts of collective art and art in its modern sense, opposing them to each other since the latter is individualistic. "Collective art" is collaborative; it allows a person to meaningfully feel their oneness with other people thus enriching them and making them more productive. Collective art is not an individual activity in "free time", it is not some kind of addition to life, it is an integral part of life itself. It answers a deep human need, and if this need remains unsatisfied, the person feels insecure and anxious, as if the need for a meaningful picture of the world remains unfulfilled. To transition from a receptive orientation to a productive one, a person must relate themselves to the world not only in a philosophical and scientific sense but also in an artistic sense. And if culture does not provide such an opportunity, the average person does not develop further than their receptive or market orientation (highlighted by the authors) (Fromm, 2005).

Fromm rightfully noted that no healthy society can be built solely on intellectual knowledge in the absence of joint artistic experience. The scientist believed that the use of traditional forms, their enrichment, and transformation will help to bring new talents that would have otherwise gone unnoticed to the surface.

It is important that collective art begins with games in kindergarten and continues in school and beyond. Fromm promoted joint dances, choir, games, orchestras, sports teams in every possible way.

These instruments can help overcome disunity, alienation, and create conditions for the revival of a true sense of community.

In "Psychoanalysis and ethics", Fromm states the importance of creative activity: "... If the attraction to creativity does not receive a real outlet, there is a gravitation towards destruction. The mental stress is such that if a person cannot unite themselves with the world in an act of creativity, the urge to eliminate and destroy the world is born. Thus, paradoxically, a person solves the problem of eliminating loneliness. Therefore, creativity and destruction are not instincts, they are responses to the human situation in a particular society. The alternative is quite clear - create or destroy ..." (Fromm, 1933). Fromm's studies support that:

1. Thoughts and feelings can not be separated in education. As an integral being, a human perceives the world as a whole. Through thinking, sciences are comprehended; with the help of feelings, the subjective comprehension of the world is expressed in the images of art. With a joint 
influence of science and art in education, art will cease to be a separate sphere of life ("this division ... is a modern phenomenon") (Fromm, 2005) but will always be relevant for a person.

2. A child is learning to respond to the world around them with the help of feelings meaningfully, productively, actively, and together with others. This is facilitated by "collective art" allowing to meaningfully experience one's unity with other people (collective art projects, stage activities, choir, orchestra, folk festivals, art exhibitions, craft festivals, etc.) enriching a person and making them more productive. Collective art must begin with play in kindergarten and continue throughout school and beyond. Shared artistic experiences contribute to a healthier society. Otherwise, "our way of life will soon destroy itself due to the lack of balance and health" (Fromm, 1933).

3. If education does not seek to teach a child to relate themselves to the world not only in the scientific but also in the artistic sense, it deprives them of the opportunity to develop leaving students at the level of receptive orientation. Artistic activity enriches the visual perception of a speech message encoded with graphic symbols allowing the transition from a receptive orientation to a productive one.

4. Connecting oneself with the world in an act of creativity allows a person to relieve mental stress, "let out" negative emotions, and strengthen the positive ones. Otherwise, there emerges a craving for destruction as a response to situations that lead a person to aggressive or depressive states. "The alternative is quite clear - create or destroy ..." (Jung, 2007).

The importance of interaction with art for the formation of the inner emotional world of a person was noted by M.F. Dostoevsky who argued that in the process of communicating with art, artistic impressions "... accumulate, break through the heart's cortex as they develop, penetrate into the very core, into the very essence, and form a person" (Dostoevsky, 1987).

Active interaction with art is a good stabilizer of the emotional sphere which is especially important in adolescence and early adulthood. Psychologists (I.S.Kon, A.V. Mudrik, P.M. Iakobson) indicate the constant expectation of communication, the desire for dialogue as the most important characteristic of this period. In interaction with other people, with the world, a person's maturation and self-determination take place. A teenager and a high school student play the role of "the other" within themselves and creatively "get into character" with the images meaningful to them. Affecting the integral personality of the perceiver, art organizes the subject's relationship with the world, ensures the harmony between a person's inner psychological space and the external world, extinguishes affects, helps both the artist and the viewer to avoid an unnecessary emotional outburst. Not without reason, L.S. Vygotsky emphasized the importance of art as a kind of neuroemotional "lightning rod". This is especially true in the modern world full of uncertainty.

According to B.I. Dodonov, the emotional sphere suffers from a lack of emotional saturation. This is especially harmful in adolescence and early adulthood. The lack of vivid impressions leads the children to their independent searches the result of which is very sad. Emotions are born in the course of the struggle for certain values (Dodonov, 1987) as one of the means of successful orientation in this struggle. The author believes that if the development of artistic values is included in the existing system of program needs of each person, the components of these programs experience, knowledge, and beliefs - will be significantly enriched and filled with new content aesthetic experience.

Physiological studies show the role of emotions in the life of the human organism and its self-regulation (Rappoport, 1968). In addition, it was found that at a certain stage of the formation of the brain, for its subsequent evolution, one cannot do without impressions as strong emotions assist in the formation and development of emotional centers of the brain the functioning of which acts as a stimulator and accelerator of mental activity, an "enzyme" of the processes of intelligence formation. E. Fromm directly associated underdevelopment and even more so the suppression of 
emotionality with the growth of destructiveness arguing that without emotions, a person suffers and loses stability (Sokolov, 1994).

There are many ways of emotional saturation directly related to art.

Art classes compensate for the lack of emotions, extinguish affects, and help sublimate negative thoughts and emotions in creative activity.

\section{Intelligence development. Intelligence and assimilation of knowledge}

In O. Hobart Mowrer's studies, emotions are viewed as the highest order of intellect (Mowrer, 1950). The works of Russian psychologists and teachers reveal that it is easier to assimilate those phenomena in the field of knowledge that have become valuable for a person (Mudrik, 1981). Considering the integration of "knowledge-experience" for the development of thinking and speech, back in the 1970s, L.I. Ruvinskii noticed a characteristic connection between the intellectual and the emotional during the assessment of the significance of a phenomenon (Sokolov, 1994). The scientist wrote: "When ... knowledge is formal, remains outside of the emotional sphere, ... information does not find support in the intellectual and emotional sphere of a student and, therefore, ... values do not acquire personally significant meaning for them" (Ruvinskii, 1974). Evaluation is viewed as an intellectual and emotional act.

The process of creating knowledge is a natural and inherent property of the cerebral cortex. Therefore, a student's activity should be organized so that "they could make some discovery for themselves as a result of which they would be able to synthesize new knowledge, draw a conclusion, formulate their definition, etc." (Kuznetsova, 1993).

Thus, it is possible to form a child's abilities only after they acquire a vital need for a particular type of activity. The pedagogical task is to make the very process of acquiring knowledge fascinating for students due to their needs for the self-creation of their personality.

\section{Socialization and identification}

In the connection between art and the social structure of society, works appear "not just as literary texts but in the aspect of their social functioning (always specifically organized and regulated)" (Krivtsun, 2003).

Art and artistic culture have diverse connections with many spheres of life participating in the complex process of development and self-determination of a person as a person. "The social effect of art is determined by the degree of influence of artistic images on the inner world of a person, on all aspects of their social activity" (Sokolov, 1994).

The semiotic sign system of culture which underlies human socialization and without which society and culture are impossible was proposed by lu.V. Rozhdestvenskii. In his interpretation, the "systems of unifying purpose" are located on the main coordinates of language (as the main means of communication uniting people), the means of counting (as the simplest means of ordering and organizing the world by temporal and spatial parameters), ceremonies and games (as the main means of education and organization of society). Between the main coordinates, there are "special purpose" systems: prognostic signs (omens, fortune-telling); signs of non-applied (music) arts (music, dance, images, and ornament); signs of applied arts (utensils, costume, architecture); control signs (measures, landmarks, commands) (Rozhdestvenskii, 2000). Summarizing the functioning of the entire structure, Rozhdestvenskii concluded that: "The entire set of sign systems not only allows the formation of society as a structural whole but also explains the nature of the socialized mental activity. Language and the means of counting require conceptual thinking; rituals and play, on the contrary, form the spiritual experiences of the individual leading to a change in their self-consciousness. Prognostics develop foresight, musical arts improve figurative thought, 
applied arts provide a feeling of comfort, and control signs give an ethical beginning to human experiences" (Rozhdestvenskii, 2000).

The evolution of the levels of culture is characterized by: 1) staying within the boundaries outlined by the folklore model; 2 ) the next level of culture does not cancel the achievements of the previous one but leads to its enrichment and restructuring; 3 ) folk arts and crafts are not canceled out by the emergence of the canons of icon painting, easel painting, photography, cinema, computer graphics, etc.

Sociologists believe that any change is always based on social interest and the emergence and deployment of new cultural forms begin with that. In this regard, it is important that the process of the formation and deployment of cultural forms changes if most members of society have lost identification and hence a meaningful understanding of their interests (Ionin, 2004).

According to L.G. Ionin, the process of a person's identification in a new cultural form is opposite to the process of the emergence of a cultural form. It begins with a subject and behavioral presentation while the decisive role is played by external attributes (clothing, accessories, speech, forms of behavior, etc.) as a sort of decoration, and the result is the formation of social interest (Ionin, 2004).

Therefore, cultural development often has an external, playful nature at first. This means that, although supported by the person, the rules of the game adopted in the new group are initially not identified with the norms of their own life. At this point, acquaintance with the new has the form of mastering external signs and the person does not yet identify themselves with this new but as soon as this game turns out to be interesting for the individual and they realize its necessity for themselves personally, they will learn a new speculative image of the world and new moral norms will become defining for them. Then we can finally state the emergence of social interest in a new way of life.

Sociological studies demonstrate that:

1. The structural integrity of society, just like the nature of the socialized mental activity, is defined by the complex of sign systems. The understanding and implementation of various sign systems significantly facilitate the process of perceiving, storing, and transmitting information. Sign systems are primarily visual and many of them are formed by the means of graphic art.

2. Language and the means of counting require conceptual thinking; art in all its manifestations forms the spiritual experiences of an individual which determine the evolution of a person's self-consciousness.

3. Due to its multifunctionality, art is involved in almost all spheres of culture and industry. In culture, it promotes communication, the social organization of society, the preservation of ethnic and historical memory, the development of ethical and aesthetic feelings, develops foresight, awakens imaginative thought. In industry, art contributes to manufacturing beautiful and usable things, devices, machines, etc. through design and ergonomics.

4. The identification of a person with their people and country is ensured by the knowledge of traditions which are guarded by art.

5. Entering a different culture, appropriating a new speculative image of the world, and new moral norms become defining for a person when they lose identification with their native country and people. Social interest in the new way of life emerges. Due to the lack of life experience and stable identification, some young people become hostages in such situations as they easily fall into the captivity of other people's interests and focus on vivid manifestations of external signs in search for their interest. Immunity of such phenomena can be ensured by the development of art which provides an idea of the basic values of the native culture and teaches a person to critically look at many manifestations and evaluate their essence. 


\section{RESULTS}

In modern psychology and pedagogics, the quality of assimilation of knowledge and information has gained fundamental importance since it is associated with the problem of leading a normal life which is possible when achieving professional success.

Ways and techniques of using the resources of art and artistic and creative activity in the general education system?

Well-known methods of effective assimilation of educational information developed by J. Martin are reflected in the so-called "Pyramid of learning". This pyramid received an extremely broad interpretation in the works of psychologists and educators. It is based on 7 methods, among which a lecture is the most ineffective (only $5 \%$ ) followed by reading (10\%), audial methods (20\%), videos (30\%), discussion (50\%), practical use of knowledge (70\%), and, finally, teaching others (90\%) (Figure 1).

Figure 1. Pyramid of learning (according to J. Martin)

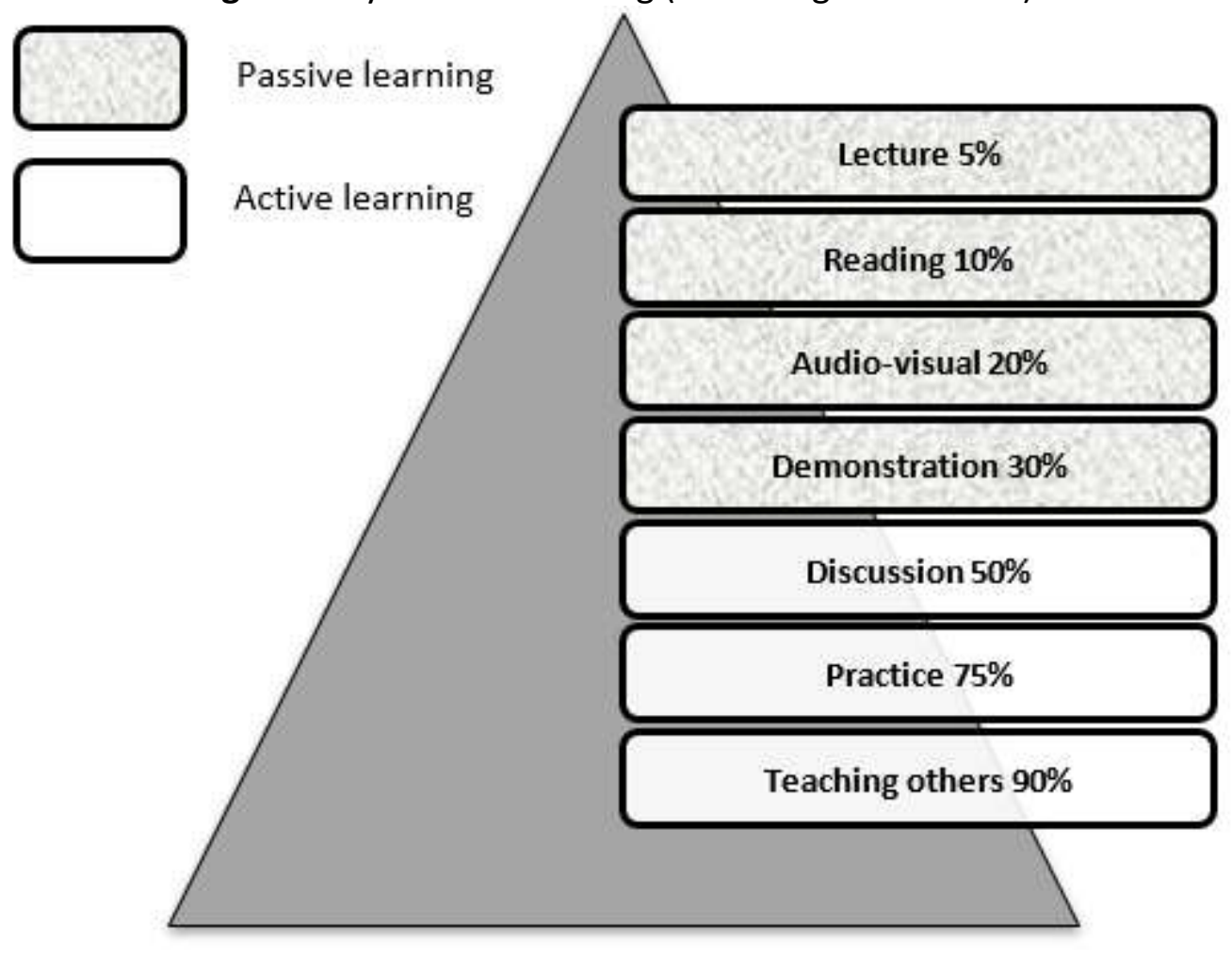

Source: The authors (2020).

Since in the real educational process a lot of time is occupied by ineffective forms such as explaining new material (lectures), independent reading, and, in the best-case scenario, demonstration or discussion, we can propose the complementary semantic approach to be used in education. The principles of said approach include complementarity of the languages of science and art in explaining the same piece of knowledge, the spatial structure of the educational process, reliance on the image, associations, resource, and recursive construction of knowledge (Kashekova, 2020).

The mechanism for the implementation of this approach in education is presented by the "ART +" cross-cultural technology (Kashekova \& Kononova, 2019).

The effectiveness of the educational process is determined by obtaining high results identified through the quantity and quality of the acquired information with the least expenditure of time and effort. Moreover, the quality is determined by the ability to use the acquired knowledge in practice in any given situation. The experience of interacting with art, interpreting its images, and 
experiencing artistic activity contribute to the development of the ability to translate an idea into an image or vice versa, an image into an idea, create an associative array, identify many different facets of a phenomenon, situation, or object, and fixate them in one's memory with signs and symbols.

The assimilation of information depends on many parameters among which are experience, memory, motivation, the level of structuring of consciousness and the cognitive sphere, etc., everything that constitutes the educational resource of a person. The development of these qualities ensures the productive assimilation of information while its absence or weak development ensures reproductive assimilation at best. The complementary semantic approach allows passive forms of learning to be made active.

It is no coincidence that the most creative psychologists argue that "it is possible and necessary to promote the artistic development of all children" (Melik-Pashaev et al., 2005). Indeed, "in the logic of education, everyone recognizes the need for a child to acquire the ability to think logically even though few people will become professional philosophers, logicians, or theoretical scientists as they reach adulthood, however, the ability to think in images which is no less important for a modern person is for some reason understood as the exclusive right of an artist" (MelikPashaev et al., 2005).

From the pedagogical standpoint, artistic development forms the skill of independent perception (understanding, evaluation), interpretation of the surrounding world, and the pursuit of an independent, creative attitude towards any kind of activity. The lack of experience in interpreting works of art, as well as generating and implementing one's creative ideas, contradicts the conditions for the development of creative qualities in a child.

As a result of the study, we can evidentiary conclude that art and artistic activity have an effective, incomparable impact on the development of intelligence, creativity, cognitive and emotional spheres, expands the relatively small life experience of an individual by supplementing it with the subjective experience of many generations of artists, writers, and composers, increases interest in the world, as well as motivation to learn its laws, and compensates for the lack of inherent memory with associative memory.

\section{CONCLUSION}

The conducted study demonstrates that the languages and methods of art used as integration mechanisms increase the possibility of mastering more information through increased emotional saturation of its content and compression in form, i.e. its "dense packing" (Kashekova \& Kononova, 2019).

The educational process designed with consideration of the language and methods of artistic activity is an integrated system that includes the content of education, its forms, and methods (Kashekova, 2020; Kashekova et al. 2020). The complementary semantic approach makes it possible to design an educational process integrated with art. This approach includes two functional levels represented by the concepts of "complementarity" and "semantics". Complementarity ensures the interconnection and complementarity of the educational process components and the semantic level reveals the symbolic essence of the received information allowing to interpret it diversely from various angles of an artistic and expressive symbol (Kashekova et al. 2020).

The complementary semantic approach using the reserves of associative thinking contributes to "unfolding" visual information and enriching it with new images. The significance of this approach in modern education is due to its effectiveness both in full-time and distance learning. The pedagogical process based on the complementary semantic approach is characterized by interaction and complementarity, operating with signs and symbols, spatial design, the recursion of building up new knowledge, and the organizing meaning of associativity and improvisation of images (Kashekova, 2020; Kashekova et al., 2020). 
In conclusion, we can state that the forms and methods of art can become the basis of pedagogical technologies for creating the educational space of a new generation of schools (Kashekova \& Kononova, 2019).

In education, art can become a universal generator of methods, approaches, and effective means of improving the quality of the educational process while motivating teachers and students, strengthening their physical and mental health, etc. at the same time.

\section{FOOTNOTE}

Perfluorinated compounds are included in the integration projects of the Siberian Branch of the Russian Academy of Sciences. The technique is based on the comprehensive fluorination of hydrocarbons. The molecular structure can be linear, branched, or contain benzene rings (Perftoruglerody - material buduschego, 2000).

Authors' Contributions: Irina E. Kashekova: conception and design, acquisition of data, analysis and interpretation of data, drafting the article, critical review of important intellectual content. Elena S. Medkova: conception and design, acquisition of data, analysis and interpretation of data, drafting the article, critical review of important intellectual content. Elena N. Piryazeva: conception and design, acquisition of data, analysis and interpretation of data, drafting the article, critical review of important intellectual content. All authors have read and approved the final version of the manuscript.

Ethics Approval: Not applicable.

Acknowledgments: We express our gratitude to the Ministry of Education of the Russian Federation for the opportunity to develop this project; to the Russian Academy of Sciences for understanding the significance of the problem and supporting its research; to the director of the Federal State Research Institution of the Russian Academy of Education "Institute of Art Education", doctor of pedagogical sciences, professor of the Russian Academy for Education E.M. Akishina for assistance in the work on the project.

\section{REFERENCES}

Arnheim, R. (2007). Iskusstvo i vizualnoe vospriiatie [Art and visual perception]. Moscow: "Arkhitektura-S".

Bekhterev, V.M. (1911). Vnushenie i vospitanie [Suggestion and education]. Report at the 1st International Pedagogical Congress in Brussels, August 13-18. Retrieved from: www.psychoreanimatology.org.

Bor, N. (1961). Filosofiia estestvoznaniia i kultury narodov [Philosophy of natural science and culture of nations], in: Atomnaia fizika i chelovecheskoe poznanie. Moscow: IL.

Davydov, V.V. (1996). Teoriia razvivaiushchego obucheniia [Theory of development-inducing learning]. Moscow: INTOR.

Dodonov, B.I. (1987). Emotsiia kak tsennost [Emotion as a value]. Moscow: Politizdat.

Dostoevsky, F.M. (1987). O russkoi literature [On Russian literature]. Moscow: Sovremennik.

Fromm, E. (1933). Psikhoanaliz i etika [Psychoanalysis and ethics]. Moscow: Respublika. 1993.

Fromm, E. (2005). Zdorovoe Obshchestvo [The Sane Society]. Moscow: “Izdatelstvo AST".

Hegel, G.W.F. (1968). Estetika [Aesthetics]. Moscow: "Iskusstvo".

Iafalian, A.F. (2011). Teoreticheskie osnovy sotsialno-khudozhestvennogo obrazovaniia [Theoretical foundations of social and artistic education]. The Surgut State Pedagogical University Bulletin, 157-163.

Ionin, L.G. (2004). Sotsiologiia kultury [Sociology of culture]. Moscow: HSE Publishing House.

Jung, C.G. (2001). Psikhologicheskie tipy [Psychological types]. Saint Petersburg: Azbuka. 2001.

Jung, C.G. (2005). Dusha i mif. Shest arkhetipov [Soul and myth. Six archetypes]. Moscow: AST.

Jung, C.G. (2007). Problemy dushi nashego vremeni [Problems of soul of our time]. Moscow: Akademicheskiy proekt.

Kashekova, I.E. (2020). Methodological problems of the complementary semantic Approach in teaching general education subjects. Revista Inclusiones, 7, 29-43. 
Kashekova, I.E. \& Kononova, E.A. (2019). Cognitive Factors of "Art+" Cross-Cultural Pedagogical Technology. International Journal of Innovative Technology and Exploring Engineering (IJITEE), 9(1), 1305-1311.

Kashekova, I.E., Piriazeva, E.N., \& Podobed, M.S. (2020). Didakticheskie vozmozhnosti komplementarnosemanticheskogo podkhoda v obuchenii budushchikh graficheskikh dizainerov [Didactic opportunities of the complementary-semantic approach in training future graphic designers]. Electronic journal "Pedagogika iskusstva", 3. Retrieved from: http://www.art-education.ru/electronic-journal

Korsybski, A. (1933). Enlace an anity. An introductions to non-Art total an y trend general emant C.N.V.

Kriulina, A.A. (2003). Ergodizain obrazovatelnogo prostranstva (Razmyshleniia psikhologa) [Ergo design of educational space (Reflections of a psychologist)]. Moscow: PER SE.

Krivtsun, O.A. (2003). Estetika: Uchebnik [Aesthetics: Textbook]. Moscow: Aspekt Press.

Kuznetsova, L.M. (1993). Ot poznavatelnogo interesa k sozidaniiu znanii [From cognitive interest to knowledge creation]. Pedagogika, 4, 35-39.

Likhachev, D.S. (2006). Zametki ob istokakh iskusstva [Notes on the origins of art]. Izbrannye trudy po russkoi i mirovoi kulture. Saint Petersburg: Saint-Petersburg University of Humanities and Social Sciences.

Losev, A.F. (2016). Dialektika mifa [Dialectics of myth]. Moscow: Azbuka.

Lotman, lu.M. (1978). Fenomen kultury [Phenomenon of culture]. Semiotika kultury. Trudy po znakovym sistemam. Uchenye zapiski tartuskogo gosudarstvennogo universiteta. Tartu.

Lotman, lu.M. (1998). Struktura khudozhestvennogo teksta [Structure of artistic text]. Ob iskusstve. Saint Petersburg: "Iskusstvo-SPb".

Martin, J. (1996). Piramida poznaniia [Pyramid of learning]. Shkola, 6, 15-18.

Melik-Pashaev, A.A., Novlianskaia, Z.N., Adaskina, A.A., Kudina, G.N., \& Chubuk, N.F. (2005). Psikhologicheskie osnovy khudozhestvennogo razvitiia [Psychological foundations of artistic development]. Moscow: Moscow State University of Psychology and Education.

Mitchell, W.J.T. (2017). Ikonologiia. Obraz. Tekst. Ideologiia [Iconology. Image. Text. Ideology.] Moscow: Kabinetnyi uchenyi.

Mowrer, O.H. (1950). Learning theory and personality dynamics. New York: Ronald Press.

Mudrik, A.V. (1981). O vospitanii starsheklassnikov [On the upbringing of high school students]. Moscow:

Prosveshchenie.

Nascimento, L. F. do, \& Cavalcante, M. M. D. (2018). Abordagem quantitativa na pesquisa em educação: investigações no cotidiano escolar. Revista Tempos e Espaços em Educação, 11(25), 249-260.

Oliveira, E. S., \& Barreto, D. A. B. (2020). Contemporary studies on knowledge, teaching in higher education and social representations in Brazil. Journal of Research and Knowledge Spreading, 1(1), e11585.

Peseschkian, N. (2006). Psikhosomatika i pozitivnaia psikhoterapiia. [Psychosomatics and positive psychotherapy]. Chelyabinsk: Institute for Positive Psychotherapy.

Rappoport, S.Kh. (1968). Iskusstvo i emotsii [Art and emotions]. Moscow: Muzyka.

Rozhdestvenskii, lu.V. (2000). Vvedenie v kulturovedenie: Uchebnoe posobie dlia vuzov [Introduction to cultural studies: a study guide for universities]. Moscow: "Dobrosvet” Publishing house.

Ruvinskii, L.I. (1974). O tsennostnom podkhode k usvoeniiu printsipov i norm nravstvennosti [On the value approach to the assimilation of the principles and norms of morality]. Sov.ped., 5, 28-34.

Santos, I. T. R., Barreto, D. A. B., \& Soares, C. V. C. O. (2020). Formative assessment in the classroom: the dialogue between teachers and students. Journal of Research and Knowledge Spreading, 1(1), e11483.

Silva, F. O., Alves, I. S., \& Oliveira, L. C. (2020). Initial teaching training by homology in PIBID: experiential learning from professional practice. Journal of Research and Knowledge Spreading, 1(1), e11638.

Silva, C. V. S., \& Santos, G. O. (2020). Digital interfaces: a methodological proposal as a strategy of teaching and learning in Mathematics classes. Journal of Research and Knowledge Spreading, 1(1), e11651.

Sokolov, K.B. (1994). Kulturologiia [Culturology]. Ocherki istorii kultury. Moscow: Interpraks. 
Vygotsky, L.S. (1997). Voobrazhenie i tvorchestvo v detskom vozraste [Imagination and creativity in childhood]. Saint Petersburg: SOiUZ. 1997.

Zinchenko, V.P. (1998). Psikhologicheskaia pedagogika. Materialy k kursu lektsii. Chast 1. Zhivoe Znanie [Psychological pedagogy. Materials for the course of lectures. Part 1. Living Knowledge]. Samara.

Received: 21 October 2020 | Accepted: 15 January 2021 | Published: 22 January 2021

This is an Open Access article distributed under the terms of the Creative Commons Attribution License, which permits unrestricted use, distribution, and reproduction in any medium, provided the original work is properly cited. 